\title{
Phaeocystis and its interaction with viruses
}

\author{
Corina P. D. Brussaard - Gunnar Bratbak • \\ Anne-Claire Baudoux • Piet Ruardij
}

Received: 10 November 2005 / Accepted: 14 February 2006 / Published online: 7 April 2007

(C) Springer Science+Business Media B.V. 2007

\begin{abstract}
Over the years, viruses have been shown to be mortality agents for a wide range of phytoplankton species, including species within the genus Phaeocystis (Prymnesiophyceae). With its polymorphic life cycle, its worldwide distribution, and the capacity of several of the Phaeocystis species to form dense blooms, this genus is a key player for our understanding of biogeochemical cycling of elements. This paper provides an overview of what is know to date about the ecological role of viruses in regulating Phaeocystis population dynamics. It explores which variables affect the algal host-virus interactions, and examines the impact of virally induced cell lysis of Phaeocystis on the function and structure of the pelagic food web as well as on the flow of organic carbon and nutrients.
\end{abstract}

Keywords Characteristics $\cdot$ Mortality Phaeocystis $\cdot$ Phycodnaviridae $\cdot \mathrm{PgV} \cdot$ Viruses

C. P. D. Brussaard $(\bowtie) \cdot$ A.-C. Baudoux $\cdot$ P. Ruardij

Department Biological Oceanography, Royal Netherlands Institute for Sea Research, P.O. Box 59, 1790AB Den Burg, The Netherlands e-mail: corina.brussaard@nioz.nl

G. Bratbak

Department of Biology, University of Bergen, Jahnebakken 5, 5020 Bergen, Norway
Abbreviations
$\mathrm{PgV} \quad$ Phaeocystis globosa virus
$\mathrm{PpV} \quad$ Phaeocysis pouchetii virus
TEP Transparent exopolymeric particles
MPN Most probable number
TEM Transmission electron microscopy
DsDNA Double-stranded DNA
HAB Harmful algal bloom species
PFGE Pulsed-field gel electrophoresis
DMS Dimethyl sulfide
DMSP Dimethylsulfoniopropionate
DOC Dissolved organic carbon
DOM Dissolved organic matter

\section{Introduction}

The presence of viruses in marine environments has been acknowledged for many years, and it is now well established that viruses are dynamic and important members of the microbial food web (Bergh et al. 1989; Proctor and Fuhrman 1990; Gobler et al. 1997; Fuhrman 1999; Wommack and Colwell 2000; Weinbauer 2004). Viruses infect not only the numerically dominant bacteria but also prokaryotic and eukaryotic primary producers. Unicellular photosynthetic organisms are a major group of organisms in natural aquatic communities and viruses have been recognized as mortality agents for phytoplankton (Van Etten et al. 1991; Reisser 1993; Brussaard 2004). Viruses or virus-like particles have 
been reported in many different taxa of eukaryotic algae, including harmful algal bloom (HAB) species (see review by Brussaard 2004; Nagasaki et al. 2004; Tomaru et al. 2004; Baudoux and Brussaard 2005).

The fate of phytoplankton biomass, whether through sinking, grazing or cell lysis, has major implications for carbon and energy cycles in marine ecosystems. Lysis-mediated release of the cellular content can greatly enhance bacterial activity and subsequently force the food web towards a more-regenerative system. Energy and nutrients released by cell lysis and excretion is transferred to higher trophic levels via the microbial loop (Azam et al. 1983). Lytic viral infection of phytoplankton causes rapid cell lysis, which may affect not only the energy and nutrient flow, but also the phytoplankton community composition and succession. Recognizing viral lysis of phytoplankton as a major process has emphasized the importance of the microbial loop including a viral shunt.

Theoretical models suggest that a $2-10 \%$ loss of phytoplankton due to viral infection increases the flow of organic carbon, bacterial production and respiration by more than 25\% (Fuhrman 1999; Wilhelm and Suttle 1999). Especially during algal blooms, when high algal cell abundances enhance the virus-host encounter rates, virally mediated lysis can have a profound effect on population dynamics, community diversity and transfer of energy and matter within the pelagic food web.

The Phaeocystis genus, with its cosmopolitan distribution, includes several high-biomass-forming species (Cadée and Hegeman 2002; Verity and Medlin 2003; Schoemann et al. 2005). Phaeocystis has a life cycle dominated by single cells (with and without flagellae) and embedded colonial non-flagellated cells. Several species of Phaeocystis, e.g., P. pouchetii and P. globosa, regularly dominate the phytoplankton community and sequester huge amounts of nutrient resources, predominantly in the form of colonies. These blooms occur mostly in colder and temperate waters, such as the coastal zone of the North Atlantic and the North Sea. Because of the importance of these blooms for the pelagic ecosystem and the socioeconomic interest in these HAB species, substantial research has been conducted on factors controlling the wax and wane of these blooms. With light and nutrients as impor- tant factors initiating Phaeocystis blooms, grazing and viruses are considered the relevant loss factors. Field studies indicate that these viruses are a dynamic component, notably involved in the decline of the blooms. Laboratory and seminatural studies provided insight into host-virus interactions and revealed how environmental factors may influence viral infection. The scope of the present paper is to provide a summary and synthesis of available information and some unpublished data related to Phaeocystis and the viruses infecting it.

\section{Isolation and characterization of viruses infecting Phaeocystis}

Viruses that infect species of Phaeocystis have been isolated during and directly after natural blooms (Jacobsen et al. 1996; Brussaard et al. 2004; Baudoux and Brussaard 2005). Phaeocystis pouchetii viruses $(\mathrm{PpV})$ were successfully isolated after 100 -fold concentration by continuous centrifugation and exposure to ultraviolet (UV) for 15 and $30 \mathrm{~s}$ (Jacobsen et al. 1996). Exposure to UV light was intended to cause induction of virus production in algal cells containing lysogenic viruses, but as the virus isolated was lytic this treatment was most likely not necessary. So far, all viruses infecting eukaryotic microalgae are lytic and none have been reported to enter a lysogenic relationship with the host. Phaeocystis globosa viruses $(\mathrm{PgV})$ were isolated from filtered (GF/F Whatman glass fiber filters) natural water that was added to exponentially growing $P$. globosa host cultures (Baudoux and Brussaard 2005). Incubation of the natural seawater with the addition of nutrients for a week at in situ temperature and irradiance (excluding UV) before adding a subsample to cultures of $P$. globosa occasionally advanced successful isolation of $\mathrm{PgV}$. At the decline of the bloom, when most free viruses can be expected to occur, nutrients regularly become depleted. By adding nutrients more algal biomass was generated and the encounter rate between algal host and virus enhanced.

The Phaeocystis viruses isolated so far are species specific, i.e., they only infect one of the Phaeocystis species (Jacobsen et al. 1996; Bau- 
doux and Brussaard 2005). Not all P. globosa or $P$. pouchetii host strains are infected by the same virus isolates, and not all viruses isolated infect the same algal host strains. There can be a high degree of specificity for these algal viruses.

All intracellular Phaeocystis virus particles observed microscopically to date have been located in the cytoplasm of the algal host cell, are hexagonal in their profile, are non-enveloped, and lack a tail. The particles are between 100 and $160 \mathrm{~nm}$ in diameter based on transmission electron microscopy (TEM) thin sectioning micrographs (particles tend to shrink when subjected to fixation and dehydration during preparation for thin sectioning). The hexagonal profiles of the viruses suggest that virions may contain an icosahedral capsid (Fig. 1). A recent investigation of the native morphology of $\mathrm{PpV}$ at a resolution of $3 \mathrm{~nm}$ using electron cryomicroscopy and three-dimensional image reconstruction methods revealed that the capsid had a maximum diameter of $220 \mathrm{~nm}$ between opposite vertices, and was composed of 2,192 capsomers that were organized in large triangular and pentagonal aggregates (Yan et al. 2005).

A common ancestor for $P$. globosa viruses and viruses infecting another prymnesiophyte (Chrysochromulina brevifilum) has also been suggested based on the phylogenetic analysis using the inferred amino acid sequences of a DNA polymerase gene fragment (Brussaard et al. 2004). This study also showed that seven $\mathrm{PgV}$ isolates formed a distinct monophyletic group with other eukaryotic algal viruses, despite differences in

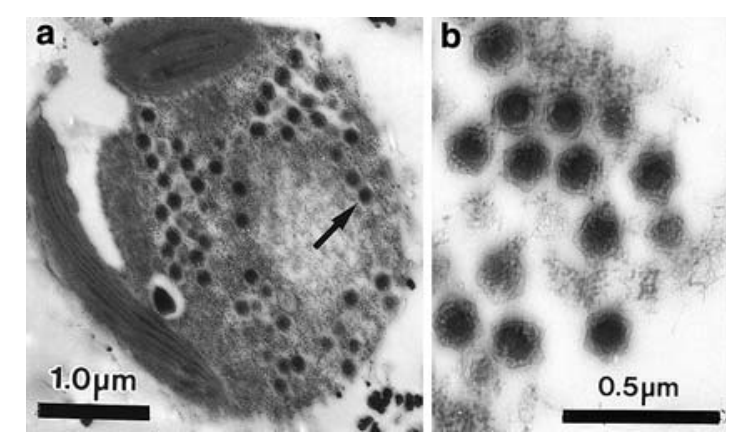

Fig. 1 Transmission electron micrographs of thin sections of infected cells of Phaeocystis pouchetii. (a) The virus-like particles (indicated by arrow) are found in the cytoplasm of the cells. (b) Detail of virus-like particles showing the hexagonal outline of the viruses their genome size and other phenotypical characteristics. Wilson et al. (2006) recently isolated a virus infecting $P$. globosa from surface water in the English Channel, UK that did not cluster with the other PgVs. Instead, it was more closely related to $C$. brevifilum.

The fact that the DNA polymerase gene could be amplified using the algal virus-specific primers AVS1 and AVS2 (Chen and Suttle 1996) allows assignment of these viruses to the family Phycodnaviridae (Van Etten 1995). Many of the characterized phytoplankton viruses are indeed assigned to this family of large double-stranded (ds) DNA viruses that infect eukaryotic algae. The use of the highly conserved DNA polymerase gene turned out to be a good genetic marker for classification of dsDNA algal viruses. The Phaeocystis viruses have indeed large dsDNA genomes, about $485 \mathrm{~kb}$ in size for $\mathrm{PpV}$ (Castberg et al. 2002), and either 177 or $466 \mathrm{~kb}$ for PgV (Fig. 2; Baudoux and Brussaard 2005). After staining with a sensitive nucleic-acid-specific dye such as SYBR Green I, these large genome sized Phaeocystis viruses could be readily detected using epifluorescent microscopy or flow cytometry (Marie et al. 1999). Furthermore, the use of flow cytometry allowed the discrimination of these viruses from other viruses such as many other algal viruses (Brussaard et al. 2000) or bacteriophages in natural samples (Larsen et al. 2001; Baudoux and Brussaard 2005). The ability to detect, discriminate and enumerate samples containing Phaeocystis viruses in a rapid and objective manner promotes laboratory research on virus-host interactions, and ecological studies in the field.

Detailed laboratory studies showed that the total length of the lytic growth cycles of the Phaeocystis viruses infecting exponentially growing host cells ranged between 25 and $50 \mathrm{~h}$ (Jacobsen et al. 1996; Baudoux and Brussaard 2005). For $\mathrm{PpV}$ the latent period, the time period from infection until the first increase in the abundance of extracellular free viruses, was around $12-18 \mathrm{~h}$ (Jacobsen et al. 1996). The study by Baudoux and Brussaard (2005) showed three different latent periods for the various $\mathrm{PgV}$ isolates in culture, i.e., 10, 12 and $16 \mathrm{~h}$ (Fig. 3). These periods match the range of latent periods for all characterized phytoplankton viruses so far, and are somewhat 


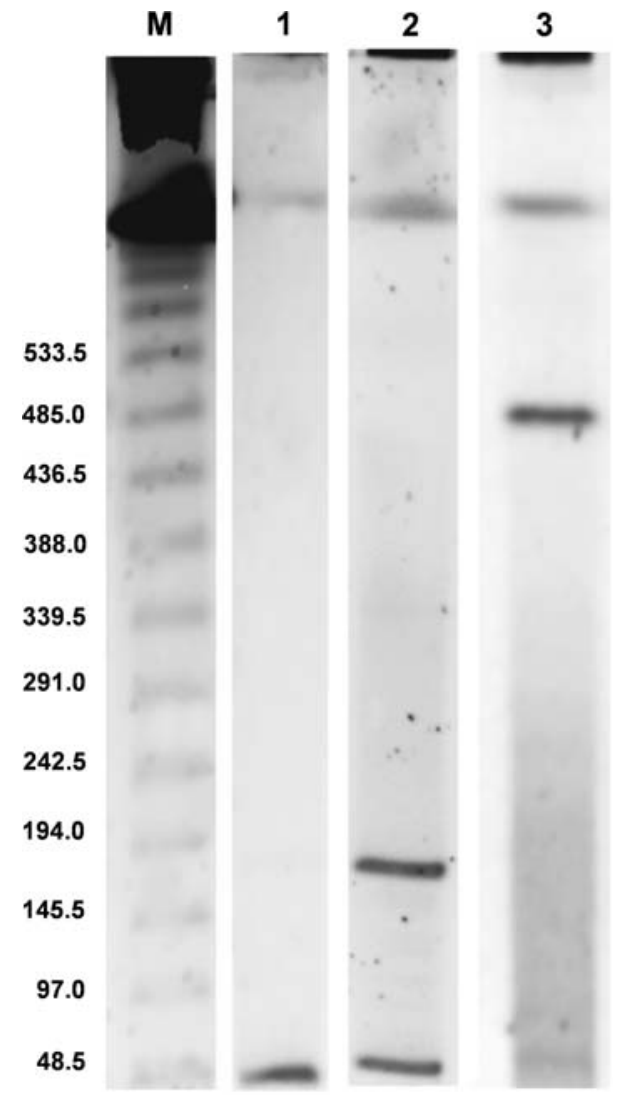

Fig. 2 Viral genome sizes of different Phaeocystis globosa virus isolates $(\mathrm{PgV})$ determined by pulsed-field gel electrophoresis (PFGE). Lane M: Lambda concatamers ladder, Lane 1: uninfected culture of P. globosa, Lane 2: PgV-04 (genome size of $175 \mathrm{~kb}$ ), Lane 3: PgV-12 T (genome size of $465 \mathrm{~kb}$ ). The small-sized band (approximately $45 \mathrm{~kb}$ ) as seen in lanes 1-3 correspond to bacteriophages since algal cultures were not axenic

shorter or comparable to the maximum growth rates of their host (Schoemann et al. 2005; Veldhuis et al. 2005). Based on the decline in the algal host population and the increase in extracellular virus particles, a conservative estimate of the burst size (number of viruses released per host cell that underwent lysis) can be estimated. For both Phaeocystis species, burst sizes ranged on average between 250 and 500, with the higher burst sizes for $P$. pouchetii. The variation in burst sizes between different $\mathrm{PgV}$ isolates was considerable, with values down to around 100 despite the exponential growth of the algal host cells (Baudoux and Brussaard 2005). Although the burst size strongly affects the chances for infection of the remaining cells in the host population, not all viruses are infectious. In exponentially growing cultures, the percentage of infective Phaeocystis viruses produced as determined by the most probable number (MPN) method is generally relatively high, ranging from 60 to about $100 \%$ (Bratbak et al. 1998; Brussaard, unpubl. data).

The devastating effect on Phaeocystis cells of an infection by lytic viruses is well illustrated by the morphological, physiological and viability status of the host population during infection (Jacobsen et al. 1996; Bratbak et al. 1998, Brussaard et al. 1999, 2001). Even though the photosynthetic apparatus of the infected algal cells seem to be active during the first hours after infection, sudden and sharp declines in the photosynthetic efficiency of the cells were observed at the end of the latent period (Fig. 4). In contrast to the above-mentioned assays, which reflect the status of the entire population, the use of flow cytometry allows the analysis of individual cells. Changes in the cell characteristics of the virally infected cells are dynamic in time, with the proportion of cells with increased cellular DNA increasing in the first hours after infection, followed by a decline in cellular scatter signals when virions are formed. Prior to cell lysis, the red autofluorescence declined concomitantly with the disruption of the organelles (as observed by transmission electron microscopy). By the time the first viruses are released from the host cells the portion of dead cells increased (Brussaard et al. 2001). Finally, during the period of cell lysis a subpopulation of cells showing reduced concentration of cellular DNA developed and increased with time.

\section{Occurrence and dynamics of Phaeocystis viruses}

Although the observations of Phaeocystis cells containing virus-like particles and the isolation of viruses infecting Phaeocystis species suggest that viruses may be potentially important, it is the succession of Phaeocystis algal cells and free viruses under seminatural conditions that implies a direct causative relationship and ecological significance. At present, two mesocosm studies and two field studies have been performed, all showing highly dynamic Phaeocystis virus abundances with time 

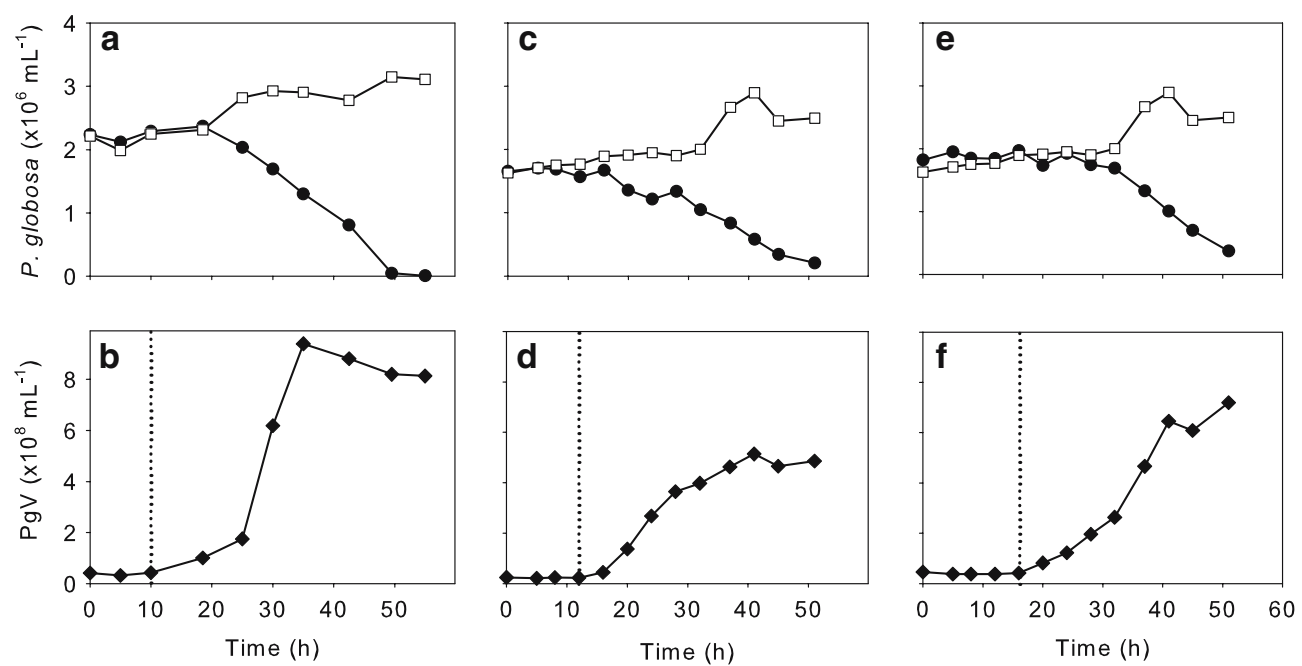

Fig. 3 Abundance of Phaeocystis globosa (a, c, e) and $\mathrm{PgV}$ $(\mathbf{b}, \mathbf{d}, \mathbf{f})$ according to Baudoux and Brussaard (2005). Open square symbols represent uninfected cultures, while the filled circles represent virally infected $P$. globosa. (a) $P$. globosa infected with PgV-07T, (c) with PgV-05T, and (e)

and closely linked to the abundance of their host (Larsen et al. 2001; Brussaard et al. 2004; Brussaard et al. 2005a; Baudoux et al. 2006). For all these studies the abundance of Phaeocystis viruses was 30 - to 100 -fold higher during bloom maxima than the abundance of their host, suggesting that viruses should indeed be regarded as important mortality agents for $P$. globosa and $P$. pouchetii. During the periods of study, the Phaeocystis viruses generally made up between 0 and $5 \%$ of the total virus population, independent of whether Phaeocystis was dominating the phytoplankton community or not. As bacteria are the numerically most abundant, the low share of Phaeocystis viruses is to be expected. However, under specific conditions favoring the single-cell morph as compared to the colonial form, the portion of $\mathrm{PgV}$ increased up to $30 \%$ of total virus abundance (Brussaard et al. 2005a). Under such conditions viruses were actually able to prevent a build-up of standing stock (i.e., bloom) of P. globosa.

A critical note here is that successful infection of Phaeocystis does not depend on the total abundance of Phaeocystis viruses, but on the number of infectious viruses. A recently published ecosystem model that was calibrated with a large data set from $P$. globosa mesocosm experiments (Ruardij et al. 2005) suggested that the fraction of with $\mathrm{PgV}-04 \mathrm{~T}$. Filled diamond symbols represent the viral growth cycles of (b) PgV-07T, (d), PgV-05T, and (f) and $\mathrm{PgV}-04 \mathrm{~T}$. The length of the latent period (indicated by the dotted line) was $10 \mathrm{~h}$ for $\mathrm{PgV}-07 \mathrm{~T}, 12 \mathrm{~h}$ for $\mathrm{PgV}-05 \mathrm{~T}$, and $16 \mathrm{~h}$ for $\mathrm{PgV}-04 \mathrm{~T}$

infective $\mathrm{PgV}$ successfully infecting $P$. globosa cells increased steeply over the course of the bloom to a maximum of 0.035 (Fig. 5). The fraction of infective $\mathrm{PgV}$ that successfully infect $P$. globosa was highest when single cells dominate. The absorption of $\mathrm{PgV}$ to transparent exopolymer particles (TEP) that are formed upon disintegration of colonies reduces the available infective $\mathrm{PgV}$ and subsequently the fraction of $\mathrm{PgV}$ that successfully infects $P$. globosa (Fig. 5). The very low value prior to bloom formation $(0.0005 \%)$ represents the situation at the start of the growing season when $\mathrm{PgV}$ standing stock was subjected for a long time (autumn till spring) to loss of infectivity and decline in actual virus particles. At the same time new virus production was insignificant for $P$. globosa when host cells were present in very low numbers and barely growing (due to light and temperature limitation during winter). A field study in the turbid coastal waters of the southern North Sea showed that the fraction of infectious $\mathrm{PgV}$ was around 0.04 (Baudoux et al., 2006), matching very well with the model situation. It is noteworthy that for $P$. pouchetii also a low host-virus adsorption efficiency was needed to produce reasonable good fit between simulation and experimental observations (Bratbak et al. 1998). 

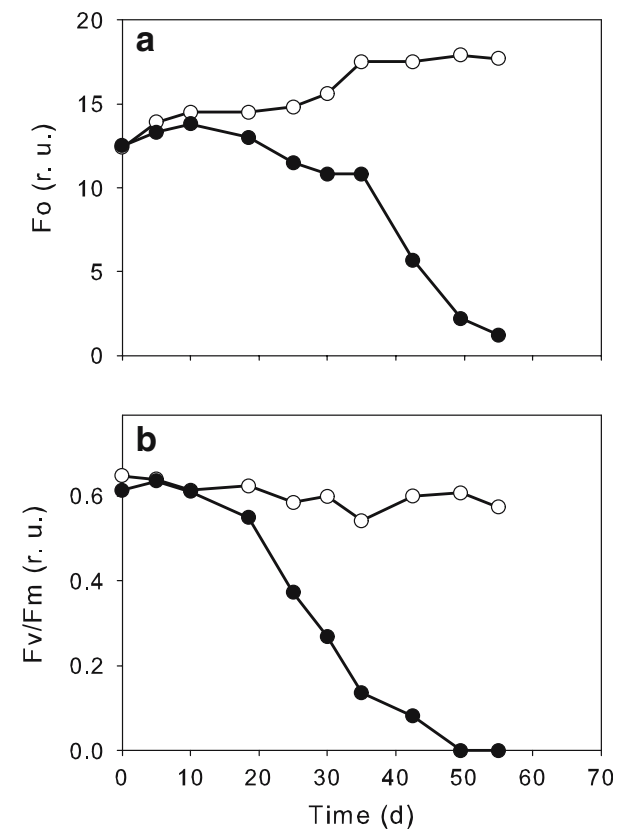

Fig. 4 Dynamics of in vivo chlorophyll fluorescence (Fo) and photosynthetic efficiency (Fv/Fm) of Phaeocystis globosa during viral infection as assessed by fluorometry. Open symbols represent uninfected cultures, while the filled symbols represent virally infected $P$. globosa. Maximum fluorescence $(\mathrm{Fm})$ was obtained after addition of the photosystem II inhibitor DCMU $(20 \mu \mathrm{M}$ final concentration). Fv equals Fm-Fo. Data are expressed in relative units (r.u.)

The strong dynamics of the Phaeocystis viruses indicate that, besides substantial production, the viral particles are also lost. Ways of removal can include passive adsorption of viruses onto the abundant organic aggregates (TEP) that are grazed upon, or onto inorganic colloids (clay, sand) that are removed from the euphotic zone by sinking (Kapuscinski and Mitchell 1980; Brussaard et al. 2005b). Other factors affecting the loss of the virus particles or infectivity are grazing by protozoa, enzymatic hydrolysis, and UV radiation as it damages the viral nucleic acids (Kapuscinski and Mitchell 1980; Suttle and Chen 1992; González and Suttle 1993; Noble and Fuhrman 1997; Jacquet and Bratbak 2003). Despite the dynamic nature and the substantial losses of PgV, phenotypic characterization and molecular analysis of $\mathrm{PgV}$ isolates collected one year apart from the same area revealed identical sequences, indicating considerable stability of these $\mathrm{PgV}$ populations
(Brussaard et al. 2004; Baudoux and Brussaard 2005). Isolation of $\mathrm{PgV}$ during periods with very low to undetectable $P$. globosa host abundance, furthermore, suggests this robust group of viruses has a constant presence in the water column in these coastal areas where Phaeocystis occurs.

\section{Diversity of Phaeocystis viruses and its ecological role}

To achieve successful infection a virus depends on the encounter rate and thus on the abundance of its host species. The Phaeocystis virus isolates have, however, not only a species-restricted host ranges but most often also a strain-specific spectrum of infection (Jacobsen et al. 1996; Baudoux and Brussaard 2005). Thus, not all strains of a Phaeocystis species (e.g., P. globosa) will become infected, even when coexisting in the same water mass. Factors influencing this are the ability of the virus to bind optimally to a proper host cell, as well as the sensitivity of the host to infection.

Based on the structural capsid protein composition, $12 \mathrm{PgV}$ isolates that originate from the southern North Sea could be divided in two groups (Baudoux and Brussaard 2005). The proteins on the surface of free viruses serve as a means of virus-to-cells attachment and allow transfer of viral genomes into the host cells. Any changes in the composition of these structural proteins between viruses may affect the binding to the host cell's receptors, selecting for host range restriction.

Considering that some of these different $\mathrm{PgV}$ isolates and their algal host strains originate from the same water sample, the ecological impact of such virus-host diversity is intriguing. Infection by a specific $\mathrm{PgV}$ does not act merely at the total host species population level, but rather on the subpopulation level. Essential advantages of such virus diversity could be the promotion of coexisting $P$. globosa strains to guarantee the availability of algal hosts. If one (dominating) strain of $P$. globosa gets infected and undergoes lysis, another resistant $P$. globosa strain that otherwise might be less fit for competition for nutrients, for example, can fill the niche. The lysis of the infected P. globosa strain 

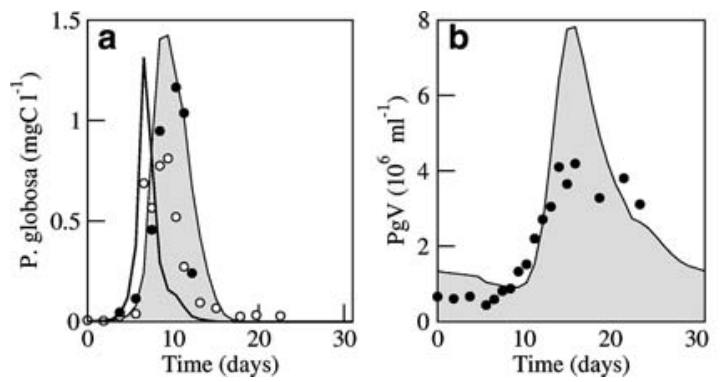

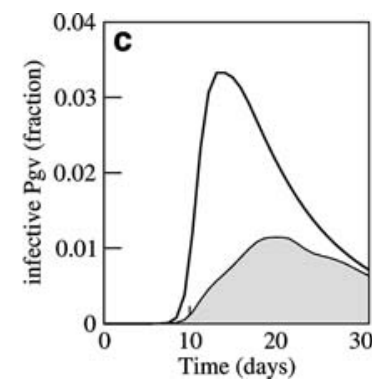

Fig. 5 Results of a mesocososm study on Phaeocystis globosa bloom dynamics and the ecological role of viruses. The measured data are represented by the symbols and the modeled results are represented by the lines. (a) measured and modeled biomass of $P$. globosa colonies (solid line and open symbol) and single cells (outline of grey area and filled symbol), (b) measured and modeled abundance of $P$. globosa viruses $(\mathrm{PgV})$, and (c) modeled fraction of infective $\mathrm{PgV}$ without transparent exopolymer particles (TEP) present (white area) and in the presence of TEP (grey area). It was assumed that infectivity declined by $10 \% \mathrm{~d}^{-1}$

for one Phaeocystis strain the susceptibility to viral infection may not be constant. A laboratory study with $P$. pouchetii showed that some algal host cells escaped infection with the lytic PpV, and with time the algal population increased in abundance again (Thyrhaug et al. 2003). Since $\mathrm{PpV}$ originating from these cultures and the original stock affected sensitive $P$. pouchetii cultures equally, the resistance to viral infection must have come from changes in the algal phenotype. Such phenotypic plasticity of the host's susceptibility to infection may be an important stabilizing factor in host-virus interactions as it seems to sustain longterm (one-year) coexistence of host and virus.

The research related to $\mathrm{PgV}$ characterization and Phaeocystis-virus interactions performed to date generally involved single cells (flagellated and non-flagellated). Phaeocystis is, however, known to form colonies and most often the embedded colonial non-flagellated cells are the predominant cell morph during bloom events. A logical question is thus if embedded colonial cells are perhaps resistant to viral infection. This question was raised already by Jacobsen et al. in 1996 upon isolation of $\mathrm{PpV}$, and it was speculated at the time that the gelatinous material the colonial cells are surrounded by serves as a protection against viral infection (Jacobsen et al. 1996; Bratbak et al. 1998). The presence of an outer thin, yet mechanically stable "skin", likely with pores $<4.4 \mathrm{~nm}$, has also been suggested as a defense against viral attack of the cells within the colony (Hamm et al. 1999). To test these hypotheses is

As discussed above, some strains of the Phaeocystis species are resistant to viral infection. But even 
nevertheless not easy as colonies will always shed at least some single cells, which become readily infected. The consequent production of viruses might thus incorrectly suggest that colonies can be infected. An attempt to infect colonial $P$. pouchetii cells with $\mathrm{PpV}$ have so far been unsuccessful (Jacobsen et al. 2005). Tests using $12 \mathrm{PgV}$ isolates to infect strains of $P$. globosa that either formed distinct colonies or mucus aggregates were unsuccessful for all but one strain of PgV (Baudoux and Brussaard 2005). Thus, mucus formation might protect Phaeocystis cells from viral infection, but the positive infection of $P$. globosa strain Pg01MD-04 by PgV-01T indicates that the protection is not exclusive.

A mesocosm experiment studying the regulatory role of viruses on $P$. globosa population dynamics sheds more light on the topic (Brussaard et al. 2005a). Both single cells and colonies originating from the same clone were present at the start of the experiment in low concentrations. The results show that the morphology of the $P$. globosa cells (solitary vs. colonial) differently regulated viral control of $P$. globosa. Under non-limiting conditions, dense blooms of colonies and to a lesser extent single cells were formed. Viruses were found to be a significant loss factor but could not prevent bloom formation. Under conditions that restricted colony formation for the first 11 days but allowed single cells to grow, viruses were found to prevent bloom formation the moment conditions were no longer limiting colony formation. The maximum standing stock of $\mathrm{PgV}$ was also fivefold higher. The results suggest that the colonial form of Phaeocystis is indeed an excellent mechanism to prevent viral infection. Interestingly, a recently developed mathematical ecosystem model including a detailed virus module (Ruardij et al. 2005) suggests that the size of the colonies strongly reduces the chance of infection per cell (and not the gelatinous matrix). The physical principle of the spherical equivalent diameter determining the encounter rate was modeled earlier by Murray and Jackson (1992). With increasing diameter of the colonies, viral infection seems an insignificant loss factor (Fig. 6). The model implies that the single cells were still readily infected, which prevented a build-up of $P$. globosa biomass. By the time colony formation

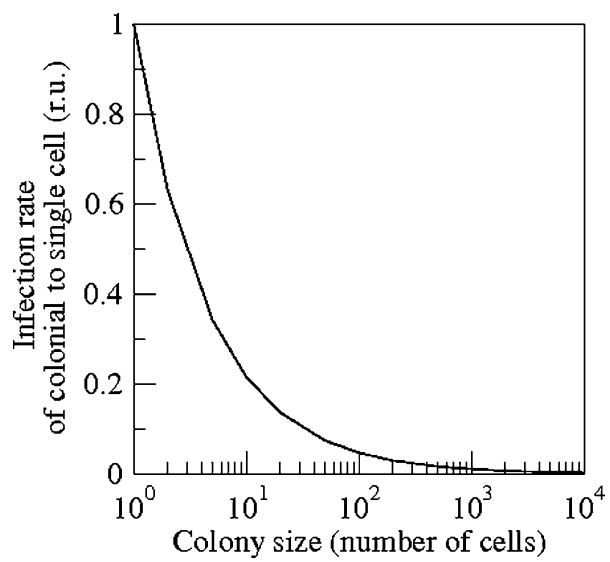

Fig. 6 Viral infection rate of $P$. globosa colonial cells embedded in a colonial matrix as compared to that of $P$. globosa single cells

was no longer limited there was not enough standing stock of single cells to form colonies.

An additional but important indirect defense mechanism against virus infection is the formation of TEP during colony disintegration. TEP was found to be a strong stabilizing negative-feedback mechanism (Brussaard et al. 2005b; Mari et al. 2005; Ruardij et al. 2005). Without colonies and thus without TEP, fewer viruses are needed to control the population of single cells.

\section{Environmental factors influencing virus-host interactions}

Keeping in mind that algal growth is regulated by environmental factors such as irradiance, nutrients and temperature, and the fact that viral replication is dependent on the metabolism of the host, it is of interest to know the impact of these factors on virus-host interactions. Under nutrient depletion, for example, the burst size of released $P$. pouchetii and P. globosa viruses per infected cell is lower than under nutrient-replete conditions, especially under P-depletion (Bratbak et al. 1998; Brussaard unpubl. data). The strongly reduced burst size found for $\mathrm{PpV}$ upon infection of $P$. pouchetii in the stationary phase of growth (15 compared to 240 cell $^{-1}$ for $P$. pouchetii in the exponential growth phase) is most likely the result of severe nutrient depletion inhibiting cell growth (Bratbak et al. 1998). 
How nutrient depletion affects not only Phaeocystis' physiology and viral replication but also indirectly the relationship between the Phaeocystis host cell and the virus becomes clear when considering the different Phaeocystis morphotypes. Cells inside the colonial matrix are barely infected, but this changes when the colonies disintegrate due to nutrient depletion. Because of the presence of a diffusive boundary layer, colony formation will decrease nutrient uptake and, therefore, colonies experience nutrient depletion faster than single cells (Ploug et al. 1999). The liberation of large numbers of single cells promotes viral infection, resulting in high viral lysis rates (Ruardij et al. 2005). Nutrient deficiency also has another mode of controlling virus-host interactions, which is by the scavenging properties of TEP. The percentage of $\mathrm{PgV}$ attached to TEP was found to be higher under $\mathrm{P}$ - than under N-deficiency and consequently the number of $\mathrm{PgV}$ for successful infection will be lower (Brussaard et al. 2005b).

Another illustration that growth conditions can affect viral kinetics is the fourfold lower burst size for $\mathrm{PpV}$-infected $P$. pouchetii when placed in the dark compared to those kept in the light. Interestingly, viral proliferation was not delayed or prevented in the dark, indicating that $\mathrm{PpV}$ was not dependent on host photosynthesis (Bratbak et al. 1998). Similar results have been found for the model system $P$. globosa-PgV (Brussaard, unpubl. data), which could indicate that this is a genus-wide feature. Since the level of irradiance strongly affects colony formation (Peperzak 1993), it also indirectly impacts on the level of viral control (Brussaard et al. 2005a).

UV radiation affected $P$. pouchetii-PpV interactions differently, depending on the type of UV radiation. UV-B radiation strongly inhibited viral infectivity, whereas UV-A radiation had no effect (Jacquet and Bratbak 2003). A fascinating additional finding was the reduced sensitivity to UV-B stress of $P$. pouchetii cells that previously escaped viral infection. Theoretically, these virus- and UV-resistant cells would have a huge advantage compared to sensitive cells. The fact that they are not dominating the population suggests that there must be a negative trade-off and it is tempting to speculate that these resistant cells may have lower growth rates due to inferior nutrient affinity. Anyway, it does stress the need for studies examining in more detail the effects of combined exposure to potentially regulating factors.

\section{Virally induced mortality of Phaeocystis}

Having established the presence, dynamics and diversity of Phaeocystis viruses, one may wonder what is the actual impact of those viruses on the loss rates of Phaeocystis. Earlier studies on $P$. globosa bloom dynamics showed that cell lysis was a relevant loss factor, with rates of up to $0.3 \mathrm{~d}^{-1}$ (Brussaard et al. 1995, 1996). Although it was not clear at that time whether viruses were causing the algal cells to undergo lysis, recent studies indicate that viruses are most likely the responsible lysis agents (Larsen et al. 2001; Brussaard et al. 2004; Baudoux and Brussaard 2005; Brussaard et al. 2005a). The use of live/dead assays indicated that viral lysis rates of infected Phaeocystis in cultures showed rates as high as $0.8 \mathrm{~d}^{-1}$ (Brussaard et al. 1999). Methods for specific and accurate determination of viral-mediated algal mortality in natural waters are however still lacking. The first attempt to estimate viral lysis rates of $P$. globosa cells during a bloom was performed for a set of mesocosm experiments (Brussaard et al. 2005a), and was based on the net production of $\mathrm{PgV}$, a conservative viral loss rate of $0.07 \mathrm{~d}^{-1}$ used to correct viral production, and an assumed viral burst size of 300 (Baudoux and Brussaard 2005). The estimated viral lysis rates were around $0.2 \mathrm{~d}^{-1}$ during the bloom, and largely accounted for most of the total cell lysis, which was either obtained using the dissolved esterase activity assay or by subtracting the net algal growth rate (equals the change in net abundance) and the microzooplankton grazing rate (using the dilution method) from the gross algal growth rate (derived from DNA cell cycle analysis).

The only field study specifically estimating virally mediated mortality of $P$. globosa cells to date (Baudoux et al. 2006) was executed using a newly developed method, being an adaptation of the classical dilution method to determine microzooplankton grazing rates (Landry and Hassett 
1982; Evans et al. 2003). Besides dilution of the natural sample in $0.2 \mu \mathrm{m}$ pore-size filtered seawater at different ratios, parallel samples were diluted in seawater that was made virus-free by ultrafiltration through $30 \mathrm{kDa}$ cartridges. As dilution results in a reduction in viral infection and/or grazing pressure, the subsequent increase in algal cell abundance after $24 \mathrm{~h}$ incubation is used to the determine the actual impact of grazing and viral lysis on the algal population. The usefulness of this adapted method for Phaeocystis was validated by testing a culture of $P$. globosa cells in the presence of viruses and the absence of grazers. During two consecutive years, natural viral lysis and microzooplankton rates were determined for $P$. globosa during the annual spring bloom events. Whereas during bloom development microzooplankton grazing seemed to be the dominant loss factor for $P$. globosa cells, viral lysis became increasingly important over the course of the bloom, with rates comparable to the grazing rates (max. $0.35 \mathrm{~d}^{-1}$ ). At times, viral lysis made up more than $50 \%$ of the total losses of the singlecell population (Baudoux et al. 2006).

Despite the dependence on certain assumptions, the discussed studies clearly imply that viral lysis is an ecologically significant mortality factor for Phaeocystis cells. Modeling also backs up the evidence that viral lysis can be an important cause of $P$. globosa cell mortality, especially under conditions where single cells dominate (Ruardij et al. 2005). Comparing model situations that lack and contain colonies, grazing as well as viral lysis are strongly enhanced with sixfold higher maximum grazing rates and 40-fold higher maximum lysis rates (Fig. 7). Colonies thus seem to have the advantage of being largely protected against grazing and viral infection, explaining their build-up of biomass (bloom). The only significant loss factor for cells inside colonies seems to be automortality, which becomes important during nutrient deficiency as a result of strongly limited nutrient diffusion (Ploug et al. 1999; Ruardij et al. 2005).

Note that the model suggests that grazing indirectly affects the impact of viral infection on the population dynamics of $P$. globosa (assuming equal grazing on both uninfected and virally infected cells). Without grazing single-cell biomass would increase faster, but viral infection would take place earlier, resulting in an overall lower standing stock of single cells (Ruardij et al. 2005).

\section{Impact of viral lysis of Phaeocystis on the microbial food web and element cycling}

From earlier studies we know that the fate of Phaeocystis primary production is of importance for the distribution of energy and biogeochemical cycling within the pelagic and benthic ecosystems (Schoemann et al. 2005). Substantial viral lysis of Phaeocystis will provide a sizable source of dissolved organic matter, thereby promoting a retentive system that oxidizes organic matter and regenerates inorganic nutrients in the euphotic zone (Brussaard et al. 1996; Gobler et al. 1997; Wilhelm and Suttle 1999; Ruardij et al. 2005).

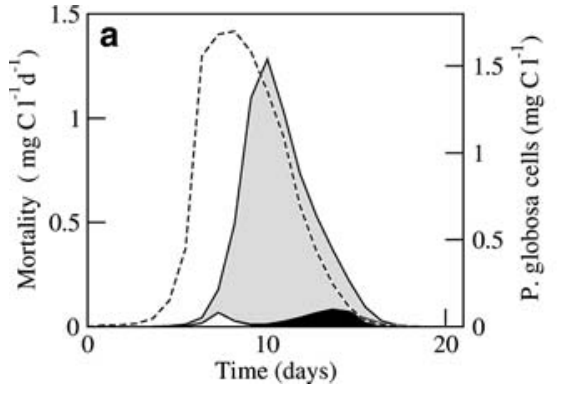

Fig. 7 Modeled abundance of Phaeocystis globosa cells and mortality rates of $P$. globosa during a mesocosm study (Ruardij et al. 2005). (a) A model run with colonies, and (b) a run without colonies present. Viral lysis is represented by the outline of the black area, microzooplankton grazing by

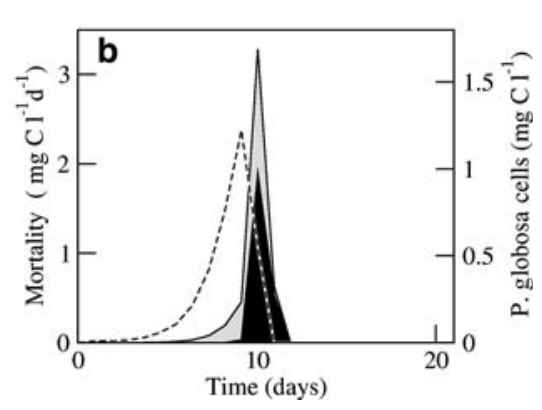

the grey area, and automortality by the white area. Automortality affects cells with a net growth rate of $<0.002 \mathrm{~d}^{-1}$, which was only found to be of importance for cells embedded in the colonies under nutrient depletion. The dotted line represents the total biomass of $P$. globosa cells 
Bratbak et al. (1998) showed that viral infection of $P$. pouchetii resulted in a conversion of the entire algal biomass to dissolved organic carbon (DOC) within three days. In contrast, this was only a maximum of $20 \%$ in the uninfected cultures. In response to viral lysis of a Phaeocystis blooms, bacterial production has been shown to increase rapidly (Brussaard et al. 2005b). Assuming a bacterial conversion factor of 0.35 (intermediate of values reported for phytoplankton cell debris and lysis products; Biddanda 1988; Van Wambeke 1994), most to all of the bacterial C demand could be accounted for by $P$. globosa cellular $\mathrm{C}$ release upon viral lysis. Concomitantly, a shift in bacterial community composition was observed, which was most likely the result of the difference in the DOC pathway. Instead of the normally slow and steady release of small amounts of photosynthetic release of DOC (favoring K-strategists or equilibrium populations), there is the sudden virally induced release of large amounts of readily degradable and organic nutrient-rich DOC (favoring r-strategists or opportunistic populations).

Most of the field data that are available to date relate to Phaeocystis blooms. Although the virally mediated cell lysis of Phaeocystis during blooms is notably substantial, there is no proof of infection of single cells beyond the bloom period. This does not mean that there could not be significant viral lysis of Phaeocystis outside the blooming period. Production of single cells can also take place at high rates when colony formation is not possible, e.g., low irradiances and nutrient concentrations. This provides not only the potential of grazing by microzooplankton, but also of viral infection of the single cells. The relatively small fraction of dissolved organic matter (DOM) obtained in this way may constitute a significant portion of the cycling of rapidly degradable carbon in the pelagic zone.

The theoretical models considering the influence of (algal) viruses on the carbon cycle that exist to date are steady-state models assuming a fixed percentage of the algal population dying due to viral lysis. A bloom of Phaeocystis in, for example, temperate eutrophic coastal waters is, however, clearly not a steady-state situation. Based on the ecosystem model by Ruardij et al. (2005), we established a carbon budget for the main players during the wax and wane of a P. globosa bloom (Fig. 8 and Table 1). P. globosa dominated primary production only when colonies were present (68\% of total), but was still one-third of the total primary production under conditions dominated by single cells. The averaged daily flux of viral lysis of $P$. globosa was tenfold higher for the model situation with only single cells present compared to the situation including colonies (115 vs. $11 \mu \mathrm{g} \mathrm{C}$ $\left.\mathrm{L}^{-1}\right)$. Without colonies, viral lysis made up for $53 \%$ of the modeled daily $P$. globosa primary production (only $2 \%$ when colonies were present).

The reason that the averaged daily uptake of $\mathrm{C}$ by bacteria is not higher under the conditions that single cells dominate (compared to colony dominated conditions) and bacterial secondary production is stimulated due to $P$. globosa viral lysis, is due to the absence of TEP production upon disintegration of colonies. Because of the large influence colonies have on the $\mathrm{C}$ cycling as a result of their high content of intracellular carbon, the $\mathrm{C}$ budget for a model run without viruses resembles largely that of the run with viruses present (data not shown). When excluding both colonies and

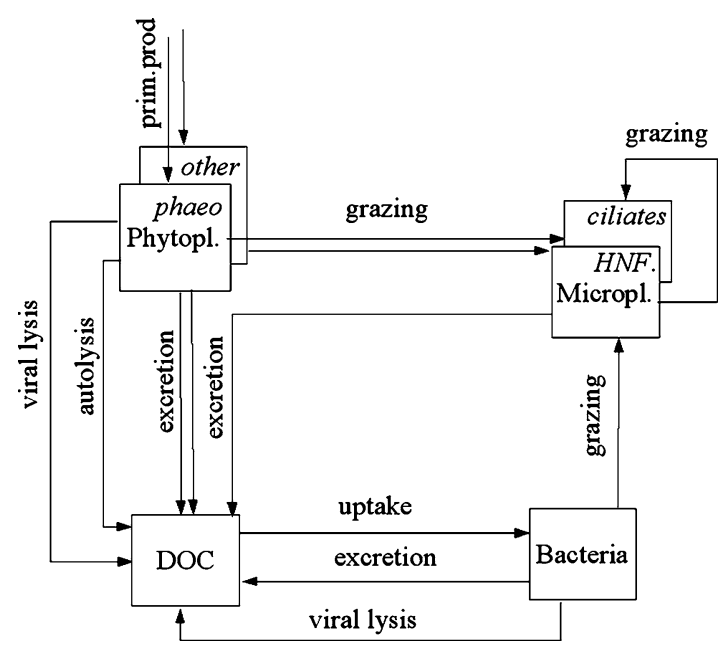

Fig. 8 Simplified representation of a pelagic food web used to calculate the $\mathrm{C}$ budget during a Phaeocystis globosa bloom as presented in Table 1. The release of cellular carbon due to viral lysis as sources of DOC, as well as automortality was only modeled for P. globosa. Excretion of DOC due to photosynthetic release was taken into account for all phytoplankton groups (Phytopl.: Phaeocystis and other algae). Micrograzers (Micropl.) include heterotrophic nanoflagellates (HNF) and ciliates. Export was considered a negligible loss 
Table 1 Modeled C budget of the wax and wane of a Phaeocystis globosa bloom (Brussaard et al. 2005a)

\begin{tabular}{|c|c|c|}
\hline & C-flux & $\left(\mu \mathrm{g} \mathrm{C} \mathrm{L}^{-1}\right)$ \\
\hline & $\begin{array}{l}\text { With colonies } \\
\text { (standard run) }\end{array}$ & No colonies \\
\hline \multicolumn{3}{|l|}{ Phytoplankton } \\
\hline $\begin{array}{l}\text { Primary production } \\
\text { P. globosa }\end{array}$ & 605 & 215 \\
\hline $\begin{array}{l}\text { Primary production } \\
\text { other algae }\end{array}$ & 290 & 435 \\
\hline Viral lysis $P$. globosa & 11 & 115 \\
\hline $\begin{array}{l}\text { Automortality } \\
\text { P. globosa }\end{array}$ & 4.2 & 0 \\
\hline Excretion $P$. globosa & 189 & 35 \\
\hline Excretion other algae & 104 & 117 \\
\hline \multicolumn{3}{|l|}{ Bacteria } \\
\hline Bacterial uptake & 614 & 364 \\
\hline Bacterial excretion & 116 & 61 \\
\hline Bacterial viral lysis & 225 & 115 \\
\hline \multicolumn{3}{|l|}{ Zooplankton } \\
\hline Grazing on bacteria & 64 & 53 \\
\hline Grazing on $P$. globosa & 158 & 62 \\
\hline Grazing on other algae & 54 & 143 \\
\hline $\begin{array}{l}\text { Grazing on } \\
\text { microzooplankton }\end{array}$ & 143 & 115 \\
\hline Zooplankton excretion & 125 & 113 \\
\hline
\end{tabular}

The daily C fluxes ( $\mu \mathrm{g} \mathrm{C} \mathrm{L}^{-1} \mathrm{~d}^{-1}$ ) originate from an ecosystem model by Ruardij et al. (2005) and are averaged values over a period of 36 days. The standard run represents the situation as was observed during the mesocosm experiment, with both $P$. globosa single cells and colonies present. Viral lysis of phytoplankton is specific for P. globosa. Viral lysis of bacteria is a second order density-dependent mortality. Respiration and high refractory DOC were modeled but are not included in the table

viruses, grazing on P. globosa becomes logically more important (data not shown). This modeling exercise suggests that Phaeocystis viruses have a significant impact on organic $\mathrm{C}$ cycling, but the underlying processes and their interactions are complex.

The lysis of cells does not only release organic carbon into the surrounding waters, but also other geochemical important elements such as, N, P, S, $\mathrm{Fe}, \mathrm{Mn}$ and $\mathrm{Zn}$ become available for biological cycling (Gobler et al. 1997; Ruardij et al. 2005). Nitrogen and phosphorus are well-known bottom-up controllers of phytoplankton productivity. Especially during periods that heterotrophic bacteria are carbon- instead of nutrient-deficient in their growth (common during Phaeocystis blooms) the shunting of lysis products through the viral shunt can result in a net remineralization of $\mathrm{N}$ and $\mathrm{P}$. Since the available inorganic nutrients can nourish algal growth again, viral infection of Phaeocystis leads to death on one side and sustained primary production of uninfected Phaeocystis strains or different phytoplankton species on the other.

Iron is a nutritive trace element whose role as a limiting agent for algal growth has been demonstrated in areas where certain Phaeocystis species (e.g., P. antarctica) are also commonly found. Viral lysis will affect the absolute concentration of iron that is potentially available for biological requirement, but may also directly affect the speciation and bioavailability as iron is mostly complexed with organic ligands and colloids.

As a major dimethyl sulfide (DMS) and dimethylsulfoniopropionate (DMSP) producer, viral lysis of Phaeocystis cells has been reported an important mechanism for the release of these organic sulphur compounds (Malin et al. 1998). Viral infection of $P$. pouchetii resulted in an eightfold increase of DMS concentration acompared to an uninfected culture. The high productivity associated with Phaeocystis blooms in combination with its world-wide distribution (Schoemann et al. 2005) makes the genus not only an important contributor to the marine carbon flux but also to the global sulphur cycle. It was estimated that the contribution of Phaeocystis to the global flux of DMS is $5-10 \%$ (Schoemann et al. 2005). As the atmospheric trace gas DMS affects cloud cover, viral lysis of Phaeocystis cells is a major link in the biogeochemical cycling of this climaterelevant element.

\section{Future perspectives}

To date viruses have been isolated and brought into culture for the bloom-forming species $P$. pouchetii and $P$. globosa. The genus includes, however, more species of which only one other is known to form a colony bloom (P. antarctica). Given the dependence of viral induced algal mortality on virus and host cell abundance, it would be of special interest to be able to bring into culture virus-host model systems of species that do not form such dense blooms and compare with 
those that do. Furthermore, the geographical distribution of the different Phaeocystis species is diverse which would provide an excellent opportunity to investigate the role of Phaeocystis viruses in the various ecosystems. A start has been by comparing the two different virus-host model systems that are available in culture, based on not only the more traditional basic virological characteristics but also on their genetic material. Full genome sequencing of $\mathrm{PpV}$ and $\mathrm{PgV}$ is currently in progress (University of Bergen, Norway and DOE-JGI). Once the sequences are available, exciting possibilities such as the development of methods for specific gene detection, function and activity assessment will be within reach.

As there are different virus types infecting the same Phaeocystis species, primer/probe development for the specific viruses will enhance our knowledge on virus diversity related issues. This type of research could also be of great help to study the ecological role of viruses for Phaeocystis during periods or in regions of low Phaeocystis abundance. Comparative genomics of the different virus types as planned for $\mathrm{PgV}$ is a challenge that is expected to provide insight into how these viruses coexist for the same host.

The newly developed data-based ecosystem model including a virus module by Ruardij et al. (2005) has proven to be very useful providing insight towards a comprehensive understanding of the role of viruses for $P$. globosa population dynamics and $\mathrm{C}$ cycling. It is, however, still far from complete. Aspects such as processes influencing PgV infectivity and losses are essentially unstudied. For example, is grazing of Phaeocystis viruses by protozoans an ecologically important loss factor? More detailed mechanistic-orientated experiments will help solve these unknowns.

Acknowledgements We acknowledge Runar Thyrhaug for providing TEM images of $\mathrm{PpV}$ viruses and $\mathrm{PpV}$ infected Phaeocystis pouchetii cells.

\section{References}

Azam F, Fenchel T, Field JG, Gray JS, Meyer-Reil LA, Thingstad F (1983) The ecological role of water-column microbes in the sea. Mar Ecol Prog Ser 10:257-263
Barker GLA, Green JC, Hayes PK, Medlin LK (1994) Preliminary results using the RAPD analysis to screen bloom populations of Emiliania huxleyi (Haptophyta). Sarsia 79:301-306

Baudoux A-C, Brussaard CPD (2005) Characterization of different viruses infecting the marine harmful algal bloom species Phaeocystis globosa. Virology 341:8090

Baudoux A-C, Noordeloos AAM, Veldhuis MJW, Brussaard CPD (2006) Virally induced mortality of Phaeocystis globosa during a spring bloom in temperate coastal waters. Aquat Microb Ecol 44:201-217

Bergh Ø, Børsheim KY, Bratbak G, Heldal M (1989) High abundance of viruses found in aquatic environments. Nature 340:467-468

Biddanda BA (1988) Microbial aggregation and degradation of phytoplankton-derived detritus in seawater. II. Microbial metabolism. Mar Ecol Prog Ser 42:89-95

Bratbak G, Jacobsen A, Heldal M (1998) Viral lysis of Phaeocystis pouchetii and bacterial secondary production. Aquat Microb Ecol 16:11-16

Bratbak G, Jacobsen A, Heldal M, Nagasaki K, Thingstad F (1998) Virus production in Phaeocystis pouchetii and its relation to host cell growth and nutrition. Aquat Microb Ecol 16:1-9

Brussaard CP, Marie D, Bratbak G (2000) Flow cytometric detection of viruses. J Virol Methods 85:175-182

Brussaard CPD (2004) Viral Control of Phytoplankton Populations - a Review. J Eukaryot Microbiol 51:125138

Brussaard CPD, Gast GJ, Van Duyl FC, Riegman R (1996) Impact of phytoplankton bloom magnitude on a pelagic microbial food web. Mar Ecol Prog Ser 144:211-221

Brussaard CPD, Kuipers B, Veldhuis MJW (2005a) A mesocosm study of Phaeocystis globosa population dynamics. I. Regulatory role of viruses in bloom control. Harmful Algae 4:859-874

Brussaard CPD, Mari X, Van Bleijswijk JDL, Veldhuis MJW (2005b) A mesocosm study of Phaeocystis globosa population dynamics. II. Significance for the microbial community. Harmful Algae 4:875-893

Brussaard CPD, Marie D, Thyrhaug R, Bratbak G (2001) Flow cytometric analysis of phytoplankton viability following viral infection. Aquat Microb Ecol 26:157-166

Brussaard CPD, Riegman R, Noordeloos AAM, Cadée GC, Witte HJ, Kop AJ, Nieuwland G, Van Duyl FC, Bak RPM (1995) Effects of grazing, sedimentation and phytoplankton cell lysis on the structure of a coastal pelagic food web. Mar Ecol Prog Ser 123:259-271

Brussaard CPD, Short SM, Frederickson CM, Suttle CA (2004) Isolation and phylogenetic analysis of novel viruses infecting the phytoplankter Phaeocystis globosa (Prymnesiophyceae). Appl Environ Microbiol 70:37003705

Brussaard CPD, Thyrhaug R, Marie D, Bratbak G (1999) Flow cytometric analyses of viral infection in two marine phytoplankton species, Micromonas pusilla (Prasinophyceae) and Phaeocystis pouchetii (Prymnesiophyceae). J Phycol 35:941-948

Cadée GC, Hegeman J (2002) Phytoplankton in the Marsdiep at the end of the 20th century; 30 years monitoring 
biomass, primary production, and Phaeocystis blooms. J Sea Res 48:97-110

Castberg T, Thyrhaug R, Larsen A, Sandaa R-A, Heldal M, Van Etten JL, Bratbak G (2002) Isolation and characterization of a virus that infects Emiliania huxleyi (Haptophyta). J Phycol 38:767-774

Chen F, Suttle CA (1996) Evolutionary relationships among large double-stranded DNA viruses that infect microalgae and other organisms as inferred from DNA polymerase genes. Virology 219:170-178

Evans CGT, Archer SD, Jacquet S, Wilson AC (2003) Direct measurements of the contribution of viral lysis and microzooplankton grazing to the decline of a $\mathrm{Mi}$ cromonas spp. population. Aquat Microb Ecol 30:207219

Fuhrman JA (1999) Marine viruses and their biogeochemical and ecological effects. Nature 399:541-548

Gobler CJ, Hutchins DA, Fisher NS, Cosper EM, SanudoWilhelmy SA (1997) Release and bioavailability of C, $\mathrm{N}, \mathrm{P}, \mathrm{Se}$, and $\mathrm{Fe}$ following viral lysis of a marine chrysophyte. Limnol Oceanogr 42:1492-1504

González JM, Suttle CA (1993) Grazing by marine nanoflagellates on viruses and virus-sized particles: ingestion and digestion. Mar Ecol Prog Ser 94:1-10

Hamm CE, Simson DA, Merkel R, Smetacek V (1999) Colonies of Phaeocystis globosa are protected by a thin but tough skin. Mar Ecol Prog Ser 187:101-111

Jacobsen A, Bratbak G, Heldal M (1996) Isolation and characterization of a virus infecting Phaeocystis pouchetii (Prymnesiophyceae). J Phycol 32:923-927

Jacobsen A, Martinez-Martinez J, Verity P, Frischer ME, Sandaa R-A, Larsen A (2005) Are colonies or colonial cells of Phaeocystis pouchetii (prymnesiophyceae) susceptible to virus infection? ASLO Summer Meeting, Santiago de Compostela, Spain, June 19-24

Jacquet S, Bratbak G (2003) Effects of ultraviolet radiation on marine virus-phytoplankton interactions. Fems Microbiol Ecol 44:279-289

Kapuscinski RB, Mitchell R (1980) Processes controlling virus inactivation in coastal waters. Wat Res 14:363371

Landry MR, Hassett RP (1982) Estimating the grazing impact of marine micro-zooplankton. Mar Biol 67:283288

Larsen A, Castberg T, Sandaa R-A, Brussaard CPD, Egge JK, Heldal M, Paulino A, Thyrhaug R, Van Hannen EJ, Bratbak G (2001) Population dynamics and diversity of phytoplankton, bacteria and viruses in a seawater enclosure. Mar Ecol Prog Ser 221:47-57

Malin G, Wilson WH, Bratbak G, Liss PS, Mann NH (1998) Elevated production of dimethylsulfide resulting from viral infection of cultures of Phaeocystis pouchetii. Limnol Oceanogr 43:1389-1393

Mari X, Rassoulzadegan F, Brussaard CPD, Wassmann P (2005) Dynamics of transparent exopolymeric particles (TEP) production by Phaeocystis globosa under $\mathrm{N}$ - or P-limitation: a controlling factor of the retention/ export balance?. Harmful Algae 4:895-914

Marie D, Brussaard CPD, Thyrhaug R, Bratbak G, Vaulot D (1999) Enumeration of marine viruses in culture and natural samples by flow cytometry. Appl Environ Microbiol 65:45-52

Murray AG, Jackson GA (1992) Viral dynamics: a model of the effects of size, shape, motion and abundance of single-celled planktonic organisms and other particles. Mar Ecol Prog Ser 89:103-116

Nagasaki K, Tomaru Y, Katanozaka N, Shirai Y, Nishida K, Itakura S, Yamaguchi M (2004) Isolation and characterization of a novel single-stranded RNA virus infecting the bloom-forming diatom Rhizosolenia setigera. Appl Environ Microbiol 70:704-711

Noble RT, Fuhrman JA (1997) Virus decay and its causes in coastal waters. Appl Environ Microbiol 63:77-83

Peperzak L (1993) Daily irradiance governs growth rate and colony formation of Phaeocystis (Prymnesiophyceae). J Plankton Res 15:809-821

Ploug H, Stolte W, Jørgensen BB (1999) Diffusive boundary layers of the colony-forming plankton alga Phaeocystis sp.-implications for nutrient uptake and cellular growth. Limnol Oceanogr 44:1959-1967

Proctor LM, Fuhrman JA (1990) Viral mortality of marine bacteria and cyanobacteria. Nature 343:60-62

Reisser W (1993) Viruses and virus-like particles of freshwater and marine eukaryotic algae - a review. Arch Protistenkd 143:257-265

Ruardij P, Veldhuis MJW, Brussaard CPD (2005) Modelling bloom dynamics of the polymorphic phytoplankter Phaeocystis globosa: impact of grazers and viruses. Harmful Algae 4:941-963

Rynearson TA, Armbrust EV (2000) DNA fingerprinting reveals extensive diversity in a field population of the centric diatom Ditylum brightwellii. Limnol Oceanogr 45:1329-1340

Rynearson TA, Armbrust EV (2004) Genetic differentiation among populations of the planktonic marine diatom Ditylum brightwellii (Bacillariophyceae). J Phycol 40:34-43

Schoemann V, Becquevort S, Stefels J, Rousseau V, Lancelot C (2005) Phaeocystis blooms in the global ocean and their controlling mechanisms: a review. J Sea Res 53:43-66

Suttle CA, Chen F (1992) Mechanisms and rates of decay of marine viruses in seawater. Appl Environ Microbiol 58:3721-3729

Thyrhaug R, Larsen A, Thingstad FT, Bratbak G (2003) Stable coexistence in marine algal host-virus systems. Mar Ecol Prog Ser 254:27-35

Tomaru Y, Katanozaka N, Nishida K, Shirai Y, Tarutani K, Yamaguchi M, Nagasaki K (2004) Isolation and characterization of two distinct types of HcRNAV, a single-stranded RNA virus infecting the bivalve-killing microalga Heterocapsa circularisquama. Aquat Microb Ecol 34:207-218

Van Etten JL (1995) Phycodnaviridae. In: Murphy FA, Fauquet CM, Mayo MA, Jarvis AW, Ghabrial SA, Summers MD, Martelli GP, Bishop DHL (eds) The classification and nomenclature of viruses. Sixth Report of the International Committee on Taxonomy of Viruses Archives of Virology. Springer Verlag, Wien/ New York 
Van Etten JL, Lane LC, Meints RH (1991) Viruses and viruslike particles of eukaryotic algae. Microb Rev 55:586-620

Van Wambeke F (1994) Influence of phytoplankton lysis or grazing on bacterial metabolism and trophic relationships. Microb Ecol 27:143-158

Veldhuis MJW, Brussaard CPD, Noordeloos AAM (2005) Living in a Phaeocystis colony; a way to be a successful algal species. Harmful Algae 4:841-858

Verity PG, Medlin LK (2003) Observations on colony formation by the cosmopolitan phytoplankton genus Phaeocystis. J Mar Syst 43:153-164

Weinbauer MG (2004) Ecology of prokaryotic viruses. FEMS Microbiol Rev 28:127-181
Wilhelm SW, Suttle CA (1999) Viruses and nutrient cycles in the sea. BioScience 49:781-788

Wilson WH, Schroeder DC, Ho J, Canty M (2006) Phylogenetic analysis of PfV-102P, a new virus from the English Channel that infects Phaeocystis globosa. J Mar Biol Ass UK 86:485-490

Wommack KE, Colwell RR (2000) Virioplankton: viruses in aquatic ecosystems. Microbiol Mol Biol Rev 64:69114

Yan X, Chipman PR, Castberg T, Bratbak G, Baker TS (2005) The marine algal virus PpV01 has an icosahedral capsid wit hT $=219$ quasisymmetry. J Virol 79:9236-9243 